\title{
The Survey of Food Consumption Among Traders with Hypertension at Bantul Traditional Market
}

\author{
${ }^{1}$ Ririn Wahyu Hidayati* \\ University 'Aisyiyah, West Ringroad 63 of Nogotirto Street Gamping Sleman 55292, Yogyakarta, Indonesia \\ ${ }^{1}$ ririnwahyu@unisayogya.ac.id* \\ *corresponding author \\ Submission date: 10 Juli 2020, Receipt date: 12 Juli 2020, Publication date: 1 November 2020
}

\begin{abstract}
Hypertension is a non-communicable disease which ranks in the top 3. Untreated hypertension will have an impact on increasing the incidence of stroke and coronary heart disease. The prevalence of hypertension in Indonesia is 25, 8\%, while the incidenceof hypertension in Special Region of Yogyakarta is 25,7\%. In Indonesia in 2017, 77\% of people with a history of hypertension had a stroke. Therefore, in 2025 it is projected that 29\% of the world's population or as many as 1.56 billion adults will experience hypertension. This is influenced by several factors, one of which is an unhealthy lifestyle. Efforts that have been made by Indonesia in the prevention and control of hypertension with "CERDIK" behavior. This study aims to determine the types of food consumed by traditional market traders in Bantul who have hypertension. The study used a simple quantitative descriptive design with cross sectional approach. The population in this study were 87 traders. Samples were taken by purposive sampling method, namely all traders who have hypertension and are willing to be respondents as many as 50 traders. This research is expected to increase public awareness independently and research data can be used as basic health data for traders and follow-up for health workers for appropriate hypertension management in the community.
\end{abstract}

Keywords: Food consumption, Hypertension, traders

\section{INTRODUCTION}

Hypertension is identical to an increase in blood pressure, systolic $\geq 140 \mathrm{mmHg}$ while diastolic $\geq 90 \mathrm{mmHg}$ after measurement (Tocci, G and Presta, V. 2017). Research conducted by Yudiarto, F et all in Indonesia in 2017 showed $77 \%$ of people having a stroke had a history of hypertension. In 2015, 54\% of all deaths were caused by ischemic heart disease and stroke. Basic Health Research (BHR) (2013), the prevalence of hypertension in Indonesia is $25.8 \%$, while in DI Yogyakarta it was $25.7 \%$. The results of the analysis of hypertension coverage among health workers were only $36.8 \%$ while $63.2 \%$ cases of hypertension in the community were undiagnosed. This shows that most hypertension sufferers do not realize that they are suffering from hypertension or are receiving treatment (DoH RI. 2017). According to Tocci, G and Presta V (2017), the prevalence of hypertension in the male and female groups has decreased however, continues to increase in the adult population in general.

This happens because a person's socio-economy and unhealthy lifestyle are at risk of having uncontrolled blood pressure. This lifestyle is like often consuming foods such as noodles, bread, biscuits, fried foods and using spices such as shrimp paste. The 
patient's dietary intake for animal protein was not good at $52 \%$, the intake of unsaturated fatty acids was $53.3 \%$, good cholesterol intake was $50.7 \%$, good sodium intake was $81.3 \%$ and the sufficient fiber intake was only $13.3 \%$ (Bertalina, B and Muliani, M. 2016).

Efforts that have been made by Indonesia in the prevention and control of hypertension include improving health promotion through IEC in controlling hypertension with "CERDIK" behavior, Socialization of Hypertension in General and Special Groups, early detection of risk factors for hypertension in general and special groups and management of hypertension sufferers. at the health facility to prevent complications (Public Healt office DIY, 2015). The results of a preliminary study conducted by researchers in Bantul traditional market indicated that 6 out of 10 traders examined had high blood pressure. This is because there are traders who have a history of hypertension and consume food as they are at the market. Fast food and can be used for "snacking".

\section{RESEARCH METHODS}

This study used a simple quantitative descriptive study with a cross sectional approach where this study measures blood pressure and looks at the dietary habits of the respondents at the same time. The target of this research is traders who have hypertension. The total population was obtained by 64 traders after calculating the sample size obtained by 54 respondents. However, during the study there were 4 respondents who dropped out because they were busy serving buyers and refused to continue being respondents. So that 50 respondents were obtained. The sample selection is done by means of purposive sample with criteria traders who have high blood pressure and are willing to take a whole series of studies.

\section{RESULTS AND DISCUSSION}

The research was conducted for 3 times 'the market day' to get the number of respondents according to the sample size calculation. The number of respondents in the study obtained as many as 50 traders with hypertension in Bantul Traditional Market. The results of the analysis of food consumption patterns can be seen based on the frequency distribution table for types of food based on the characteristics of the respondents.

Table 1. Diet of Hypertension Patients based on characteristics

\begin{tabular}{|c|c|c|c|c|c|c|c|}
\hline \multirow{2}{*}{ Characteristics } & \multirow{2}{*}{ Type of Food } & \multicolumn{2}{|c|}{ Often } & \multicolumn{2}{|c|}{ Rarely } & \multicolumn{2}{|c|}{ Never } \\
\hline & & $F$ & $\%$ & $f$ & $\%$ & $f$ & $\%$ \\
\hline \multicolumn{8}{|l|}{ Gender } \\
\hline \multirow[t]{4}{*}{$\mathrm{P}$} & $\mathrm{L}$ & 6 & 12 & 17 & 34 & 8 & 16 \\
\hline & $\mathrm{N}$ & 4 & 8 & 15 & 30 & 12 & 24 \\
\hline & $\mathrm{Se}$ & 4 & 8 & 16 & 32 & 11 & 22 \\
\hline & $\mathrm{K}$ & 10 & 20 & 15 & 30 & 6 & 12 \\
\hline \multirow[t]{4}{*}{$\mathrm{L}$} & $\mathrm{L}$ & 4 & 8 & 8 & 16 & 7 & 14 \\
\hline & $\mathrm{N}$ & 3 & 6 & 10 & 20 & 6 & 12 \\
\hline & $\mathrm{Se}$ & 4 & 8 & 11 & 22 & 4 & 8 \\
\hline & $\mathrm{K}$ & 5 & 10 & 12 & 24 & 2 & 4 \\
\hline \multicolumn{8}{|l|}{ Age } \\
\hline $35-44$ & $\mathrm{~L}$ & 0 & 0 & 6 & 12 & 3 & 6 \\
\hline & $\mathrm{N}$ & 2 & 4 & 4 & 8 & 3 & 6 \\
\hline & $\mathrm{Se}$ & 2 & 4 & 6 & 12 & 1 & 2 \\
\hline
\end{tabular}




\begin{tabular}{|c|c|c|c|c|c|c|c|}
\hline & $\mathrm{K}$ & 3 & 6 & 5 & 10 & 1 & 2 \\
\hline \multirow[t]{4}{*}{$45-54$} & $\mathrm{~L}$ & 3 & 6 & 10 & 20 & 5 & 10 \\
\hline & $\mathrm{N}$ & 2 & 4 & 12 & 24 & 4 & 8 \\
\hline & $\mathrm{Se}$ & 2 & 4 & 12 & 24 & 4 & 8 \\
\hline & $\mathrm{K}$ & 5 & 10 & 9 & 18 & 4 & 8 \\
\hline \multirow[t]{4}{*}{$55-64$} & $\mathrm{~L}$ & 5 & 10 & 9 & 18 & 2 & 4 \\
\hline & $\mathrm{N}$ & 0 & 0 & 10 & 20 & 6 & 12 \\
\hline & $\mathrm{Se}$ & 4 & 8 & 9 & 18 & 3 & 6 \\
\hline & $\mathrm{K}$ & 4 & 8 & 7 & 14 & 5 & 10 \\
\hline \multirow{4}{*}{$65-74$} & $\mathrm{~L}$ & 1 & 2 & 4 & 8 & 2 & 4 \\
\hline & $\mathrm{N}$ & 0 & 0 & 4 & 8 & 3 & 6 \\
\hline & $\mathrm{Se}$ & 1 & 2 & 4 & 8 & 2 & 4 \\
\hline & $\mathrm{K}$ & 3 & 6 & 3 & 6 & 1 & 2 \\
\hline \multicolumn{8}{|l|}{ BMI } \\
\hline \multirow[t]{4}{*}{ Normal } & $\mathrm{L}$ & 6 & 12 & 14 & 28 & 6 & 12 \\
\hline & $\mathrm{N}$ & 3 & 6 & 15 & 30 & 8 & 16 \\
\hline & $\mathrm{Se}$ & 6 & 12 & 16 & 32 & 4 & 8 \\
\hline & $\mathrm{K}$ & 9 & 18 & 12 & 24 & 5 & 10 \\
\hline \multirow[t]{4}{*}{ Fat } & $\mathrm{L}$ & 4 & 8 & 15 & 30 & 5 & 10 \\
\hline & $\mathrm{N}$ & 2 & 4 & 13 & 26 & 9 & 18 \\
\hline & $\mathrm{Se}$ & 2 & 4 & 17 & 34 & 5 & 10 \\
\hline & $\mathrm{K}$ & 7 & 14 & 14 & 28 & 3 & 6 \\
\hline \multicolumn{8}{|l|}{ HT history } \\
\hline \multirow[t]{4}{*}{ There is } & $\mathrm{L}$ & 4 & 8 & 18 & 36 & 8 & 16 \\
\hline & $\mathrm{N}$ & 5 & 10 & 16 & 32 & 9 & 18 \\
\hline & $\mathrm{Se}$ & 7 & 14 & 18 & 36 & 5 & 10 \\
\hline & $\mathrm{K}$ & 6 & 12 & 15 & 30 & 9 & 18 \\
\hline \multirow[t]{4}{*}{ There is no } & $\mathrm{L}$ & 4 & 8 & 13 & 26 & 3 & 6 \\
\hline & $\mathrm{N}$ & 1 & 2 & 12 & 24 & 7 & 14 \\
\hline & $\mathrm{Se}$ & 2 & 4 & 14 & 28 & 4 & 8 \\
\hline & $\mathrm{K}$ & 6 & 12 & 9 & 18 & 5 & 10 \\
\hline
\end{tabular}

Ket: $\mathrm{L}=$ Fat, $\mathrm{N}=$ Sodium, $\mathrm{Se}=$ Fiber, $\mathrm{K}=$ Potassium

According to Hardinsyah and Supariasa, ID N (2016), hypertension can be caused by factors that cannot be changed (age, gender, and genetic factors) and factors that can be changed (diet and body weight). Based on the results of the study, the dietary patterns of hypertensive patients based on age, gender, genetic factors, and body weight (BMI) were discussed as follows.

1.Diet of Hypertension Patients Based on Gender

The results of the study found that 17 respondents (34\%) had a diet with hypertension based on female gender. Respondents in this study conveyed the frequently consumed fats in the form of chicken and chicken skin, mutton, fried foods which are used as snacks on the sidelines of trading. According to Kurniawan, A. (2012) states that excessive fat consumption can increase blood cholesterol levels, especially Low Density Lipoprotein (LDL) cholesterol levels. Cholesterol will stick to the walls of the blood vessels to form plaque. Plaque will clog the blood vessels and this can affect the flexibility of the blood vessels. Katsilambros, N, et al. (2013) people with hypertension are advised to consume $\leq 6$ servings of lean meat, poultry and fish a day, 2 3 servings of fat-free or low-fat milk and dairy products / day, while 2-3 portions of fat and oil / day with a size of 1 teaspoon. Kartika, LA et al. (2016) found that 42 respondents $(87.50 \%)$ had hypertension who consumed high-fat foods. The results of this study also showed that 10 respondents (20\%) had a frequent potassium diet. Potassium helps in many biochemical reactions such as release of energy from food, 
glycogen and protein synthesis (Hasdianah et al. 2014). Assisted by the hormone estrogen which can stimulate binding or transport protein synthesis in the liver (Dawn B. et al. 2013). In addition, potassium also plays a role as part of the enzyme (Hardiansyah and Supariasa, I. 2016). Thus, women's energy needs are still met.

In contrast to the male gender, 10 respondents $(20 \%)$ have a sodium diet which is obtained from the types of salted egg, salted chips, and milkfish. Excessive sodium consumption causes the composition of sodium in the extracellular fluid to increase. To normalize again, the intracellular fluid must be withdrawn so that the extracellular fluid volume increases. The increase in extracellular fluid volume causes an increase in blood volume which results in the emergence of hypertension (Hardinsyah and Supariasa, IDN 2016). This study also found that $8 \%$ of men had never had a fiber diet. Respondents have a dietary fiber with the types of food such as spinach, kale, mustard greens, green beans, cucumber, luffa, papaya $2 \mathrm{x} /$ week, peanuts $2 \mathrm{x} /$ week while tempeh and tofu 2-3x / day. Katsilambros, N, et al. (2013) argue that people with hypertension are advised to consume food groups of fruits 4-5 servings a day, wheat groups 6-8 servings / day, vegetable groups 4-5 servings / day, and food groups of nuts, seeds and nuts. legumes as many as 4-5 servings / week. Marquez, FZ et. al (2017). A diet high in fiber causes changes in the gut microbiota that play a protective role in the development of cardiovascular disease. The beneficial effects of fiber can be explained by the generation and distribution of one of the main metabolites of the gut microbiota, the short-chain fatty acid acetate. Acetate induces several molecular changes associated with improved cardiovascular function and health. In addition, the consumption of potassium is often found in the male gender (24\%). Assisted by calorie storage (triacylglycerols) in adipose tissue, where triacylglycerols contain more calories per gram compared to carbohydrates or protein. Thus, men's energy needs are still met even though they rarely have a diet of fiber and sodium (Dwan, B. et. Al. 2013).

Female and male hypertensive sufferers rarely have a dietary fiber, this is indicated by the female gender who has a rare fiber diet as many as 16 respondents $(32 \%)$ and the male gender has a rare fiber diet as many as 11 respondents $(22 \%)$. This is because the traders only rely on cooked vegetables that are sold or fruits that are easily found in the market. The lack of food availability in the community has an impact on dietary behavior (Wrobleski. 2010). However, people with hypertension had reduced the fat diet by 8 respondents $(16 \%)$ for the female gender, and 12 respondents $(24 \%)$ had the sodium diet. This is because, traders have known fatty and salty foods can increase blood pressure.

Knowledge or cognitive is an important domain for the formation of one's actions. Based on this concept, it can be explained that the increasing knowledge of a person about hypertension will encourage a person to behave better in controlling hypertension so that his blood pressure remains under control. This good behavior can be applied by changing lifestyles such as limiting fatty foods and reducing salty foods (Jayanti Wulansari, et all, 2013).

2. Diet of Hypertension Patients by Age

This study found the diet of people with hypertension based on age 35-44 had a dietary fiber that was rare by 6 respondents (12\%), based on age 45-54 had a dietary pattern of rare sodium by 12 respondents (24\%), based on age 55-64 9 respondents $(18 \%)$ rarely consumed fiber, while based on the ages of $65-74,4$ respondents rarely had a diet of fiber and never had a sodium diet respectively (8\%). The results of interviews conducted by researchers, dietary patterns of spinach, kale, mustard greens, 
green beans, cucumbers, luffa, papaya $2 \mathrm{x} /$ week, peanuts $2 \mathrm{x} /$ week while tempeh and tofu 2-3x / day, salted eggs $2 \mathrm{x} /$ month, salted chips $2 \mathrm{x} /$ week, and milkfish $2 \mathrm{x} /$ week, do not consume sardines and shrimp paste.

The diet of people with hypertension at all ages rarely has a diet of fiber, but aged 35-44 years have reduced the diet of fat, indicated by 6 respondents (12\%) who rarely have a diet. Age 45-54 years and ages 55-64 have reduced sodium diet by 12 respondents (24\%) and 10 respondents (20\%). Meanwhile, at the age of 65-74 years, 3 respondents $(6 \%)$ never had a sodium diet. Based on the results of interviews conducted by researchers, traders have a dietary fiber diet because there are several types of vegetables which are taboo for other comorbidities and decreased appetite.

According to Mary E. Barasi (2009), a person's diet is influenced by psychological factors such as appetite and eversion (abstinence). As we get older, nutritional needs change due to increased morbidity and degenerative diseases. A decrease in the taste of the tongue and the body's ability to digest food can also affect the diet of the elderly (Waryana, 2010). If you don't clean your mouth, your teeth and gums are often infected. The secretion of saliva decreases by about $75 \%$ resulting in drying of the oral cavity, and possibly decreasing taste. Swallowing disorders caused by neuromuscular disorders, the lining of the stomach is thinning due to reduced HCI and pepsin secretion (Arisman, MB. 2014).

\section{Diet of Hypertension Patients Based on BMI}

This study found that hypertensive patients with a normal BMI had a dietary natrium and fiber as many as 15 respondents (30\%) and 16 respondents (32\%), respectively. Meanwhile, 17 respondents (34\%) had a diet with rare fiber.

Research conducted by Ramadhani, DH et al (2017), stated that patients with hypertension had insufficient fiber intake as many as 17 samples (68.0\%). Wang (2012) said that people who consume less fruit and vegetables usually have an unhealthy lifestyle so they can raise blood pressure. Marquez, FZ et. al (2017) a diet high in fiber causes changes in the gut microbiota that play a protective role in the development of cardiovascular disease. The beneficial effects of fiber can be explained by the generation and distribution of one of the main metabolites of the gut microbiota, the short-chain fatty acid acetate. Acetate induces several molecular changes associated with improved cardiovascular function and health.

This study found a normal BMI to have a diet of sparse fiber, but a diet of potassium as many as 9 respondents (18\%). Potassium helps in many biochemical reactions such as release of energy from food, glycogen and protein synthesis (Hasdianah et al. 2014). In addition, potassium also plays a role as part of the enzyme (Hardiansyah and Supariasa, I. 2016). Therefore, a person can control their diet.

The study also found that obese BMI had rare fiber diet as many as 17 respondents (34\%), but had a potassium diet as many as 7 respondents (14\%) and 9 respondents $(18 \%)$ never had a sodium diet. Excess sodium consumption can cause an increase in blood pressure due to an imbalance of the body's intracellular and extracellular fluids (Hardinsyah and Supariasa, IDN 2016). However, when the sodium level in the blood is normal. Together with potassium, sodium functions to regulate the balance of wet blood acids, balance of body fluids, regulate muscle contraction and stimulate nerves (Simanjuntak, TPT 2014). In addition, potassium plays a role in the formation of energy and potassium is part of an enzyme so that it can help in the body's metabolism.

Diets of hypertensive patients based on normal BMI and obese BMI both rarely have dietary fiber, fat and sodium. This is influenced by external factors, namely the 
availability of fiber food in the Beringharjo market. In addition, due to the traders' knowledge of diet which can lead to increased blood pressure (Wrobleski. 2010 and Notoatmodjo. 2012). However, traders with a normal BMI had a potassium diet as many as 9 respondents (18\%) while obese BMI with a frequent potassium diet was 7 respondents (14\%). The results of interviews conducted by researchers, traders with normal BMI prefer milk consumption. According to Mary E. Barasi (2009), a person's diet basically cannot be formed by itself, various factors affect one's food choices such as preferences which are formed from frequent contact with these foods and early learning processes (when first introduced). on food).

4. Diet of Hypertension Patients based on genetic

This study found that 18 respondents (36\%) had a dietary pattern of hypertension sufferers who had a family history of low-fiber diet. Meanwhile, the diet of people with hypertension without a family history of hypertension also rarely had a dietary fiber by 14 respondents $(28 \%)$.

Mundung, B., et al (2017) that $74.4 \%$ of respondents who have hypertension have a family history of hypertension. The results of research conducted by Asriati (2014) stated that people who have a family history of hypertension have a 2.43 times risk of developing hypertension compared to those who do not have a family history of hypertension. This study found hypertensive patients with a genetic history but rarely had a diet of fiber.

Research conducted by Ramadhani, DH et al (2017), stated that patients with hypertension had insufficient fiber intake as many as 17 samples (68.0\%). Wang (2012) said that people who consume less fruit and vegetables usually have an unhealthy lifestyle so they can raise blood pressure. Marquez, FZ et. al (2017) A diet high in fiber causes changes in the gut microbiota that play a protective role in the development of cardiovascular disease. The beneficial effects of fiber can be explained by the generation and distribution of one of the main metabolites of the gut microbiota, the short-chain fatty acid acetate. Acetate induces several molecular changes associated with improved cardiovascular function and health.

The study found that although a diet based on characteristics there was no history of rarely having diet of fiber. However, it was found that 6 respondents had a frequent potassium diet, potassium has a role in biochemical reactions such as the release of energy from food, glycogen and protein synthesis (Hasdianah et al. 2014). In addition, potassium also plays a role as part of the enzyme (Hardiansyah and Supariasa, I. 2016). So, a person's nutritional needs are still met and can control their food.

Diets based on the characteristics of having a genetic history have a diet of rare fiber, but there are still 4 respondents $(8 \%)$ who have a frequent fat diet. Fat contained in the body will fall into the category of fatty acids and triacylglycerols, which function as fuel and are the main source of energy for the body. Cholesterol also functions in the digestion and absorption of fat. In addition, cholesterol also functions as a precursor to steroid hormones which have functions including regulating metabolism (Dwan, B. et. Al. 2013). Coupled with fiber that can generate and distribute one of the main metabolites of the intestinal microbiota, short chain fatty acid acetate. Acetate induces several molecular changes associated with improved cardiovascular function and health according to Marquez, FZ et. al (2017).

The dietary pattern of hypertensive patients based on historical characteristics and no history of hypertension has a diet of infrequent fiber, however, the diet of hypertensive patients based on history also has a diet of rare potassium which can be 
seen from the diet of rare potassium by 15 respondents. This is due to the limited availability of fiber foods sold in the market and there are some traders who do not like to drink milk or because of economic factors so that traders cannot drink milk every day. Therefore, market traders only rely on bananas as the fulfillment of potassium nutrients.

Wrobleski (2010) argues that lack of food in the community has an impact on diatery behavior. Other than that, Mary E. Barasi (2009) argues that a person's diet can be influenced by psychological factors such as a preference for food, as well as external factors such as economic factors. The higher the economic status, the more amount and type of food that can be obtained. On the other hand, people living in poverty or on a low income have very limited opportunities to choose food.

\section{CONCLUSION}

17 emale respondents had rarely consumed fat and 12 respondents never consumed sodium. While 7 male respondents have never consumed fat, 5 respondents have frequently consumed high potassium. Respondents aged 55-64 years have reduced fat a lot (10 respondents) and have never consumed sodium (6 respondents). However, there are 12 respondents aged 45-54 years who rarely consume fiber. There are 9 respondents with a obsese BMI and 8 respondents with a normal BMI no longer consuming sodium, but there are still fat and normal BMI respondents who rarely consume fiber, respectively 17 and 16 respondents. There were 9 respondents who had a history of hypertension who did not consume sodium, but there were still 18 respondents who rarely consumed fiber and 9 respondents who never consumed potassium.

\section{REFERENCES}

Arisman. (2014). Gizi Dalam Daur Kehidupan: Buku Ajar Ilmu Gizi. Jakarta: EGC Asriati. (2014). Faktor Risiko Riwayat Keluarga, Status Gizi dan Riwayat Diabetes Melitus terhadap Kejadian Hipertensi Lansia di Wilayah Kerja Puskesmas Pattingalloang. Skripsi. (online) http://repository.unhas.ac.id diakses pada 9 Maret 2018

Bertalina, B dan Muliani, M. (2016). Hubungan Pola Makan, Asupan Makanan dan Obesitas Sentral dengan Hipertensi di Puskesmas Rajabasa Indah Bandar Lampung. Jurnal Kesehatan. Vol. 7 No. 1. (online) http://poltekkes-tjk.ac.id diakses pada 17 Desember 2017

Dawn, B. Allan, D. Smith, C. M; alih bahasa, Brahm, U. (2013). Biokimia Kedokteran Dasar. Jakarta: EGC

Departemen Kesehatan RI. (2017). Sebagian Besar Penderita Hiertensi tidak Menyadarinya. (online) http://www.depkes.go.id diakses pada 17 Desember 2017

Dinas Kesehatan DIY. (2015). Seksi Pengendalian Penyakit Dinas Kesehatan Kota Yogyakarta. Yogyakarta: Dinas Kesehatan D. I. Y

Hardinsyah dan Supariasa, I. D. N. (2016). Ilmu Gizi: Teori \& Aplikasi. Jakarta: EGC

Jayanti W. Burhannudin I. Devi U. (2013). Hubungan Pengetahuan Tentang Hipertensi Dengan Pengendalian Tekanan Darah Pada Pasien Hipertensi Di Poliklinik Penyakit Dalam Rsud Dr.Moewardi Surakarta. Biomedika. Vol. 5 No.1. (online) http://journals.ums.ac.id/index.php/biomedika/article/view/271 pada 18 Juli 2018. 
Katsilambros, N. Dimosthenopoulos, C. Kontogianni, M. et all. (2016). Asuhan Gizi Klinik. Jakarta: EGC

Kartika, L. A dan Afifah, E. Suryani, I. (2016). Asupan Lemak dan Aktivitas Fisik Serta Hubungannya dengan Kejadian Hipertensi pada Pasien Rawat Jalan. Jurnal Gizi dan Dietetik Indonesia. Vol. 4. No. 3. (online) http://ejournal.almaata.ac.id diakses pada 11 Juli 2017

Mary E. Barasi. (2009). Ilmu Gizi. Jakarta: Erlangga

Marquez, F. Z. Nelson, E. Chu. P. et. al. (2017). High-Fiber Diet and Acetate Supplementation Change the Gut Microbiota and Prevent the Development of Hypertension and Heart Failure in Hypertensive Mice. Original Research article. (online) http://circ.ahajournals.org/content/135/10/964.short pada 18 Juli 2018

Mundung, B. Kandaou, G. Kaunang, G. (2017). Hubungan Antara Faktor Risiko Dengan Kejadian Penyakit Hipertensi Pada Perempuan Di Wilayah Masyarakat Pesisir Desa Marinsow Kecamatan Likupang Timur Kabupaten Minahasa Utara Tahun 2017. Media Kesehatan Vol. 9 No.3. (online) http://ejournalhealth.com diakses pada 9 Maret 2018

Notoadmodjo. (2012). Promosi Penelitian Kesehatan. Jakarta: Rineka Cipta

Ramadhani, D. H. Bintanah, S. Handarsari, E. Profil Tekanan Darah Berdasarkan Asupan Lemak, Serat dan IMT Pasien Hipertensi. Jurnal Gizi. Vol. 6 No. 2. (online) http://jurnal.unimus.ac.id pada 25 Desember 2017

Riset Kesehatan Dasar. (2013). Riset Kesehatan Dasar (RISKESDAS 2013). Jakarta: Badan Penelitian Dan Pengembangan Kesehatan.

Tocci, G and Presta, V. (2017). Time Trend Analysis Of Hypertension Prevalence, Awareness, Treatment And Control In Italy: Novel Insights From Recent National Survey The General Population. High Blood Pressure \& Carciovascular Prevention Vol. 24. Iss. 2. (online) https://link.springer.com diakses pada 17 Desemeber 2017

Wang. (2012). Hubungan Asupan Serat dan Status Gizi dengan Tekanan Darah pada Wanita Menopause di Desa Kuwiran Kecamatan Banyudono Kabupaten Boyolali. Skripsi. (online) http://eprints.ums.ac.id diakses pada 25 Desember 2017

Waryana. (2010). Gizi Reproduksi. Yogyakarta: Pustaka Rihama

Yudiarto, F. Machfoed, M. H. (2017). Hypertension Is The Most Risk Factor Stroke In Indonesia Stroke Registry (P3. 262). Neurology. (online) http://n.neurology.org pada 17 Desember 2017 